\title{
AN ARAMAIC DISPUTE BETWEEN THE MONTHS BY SAHLAN BEN AVRAHAM
}

\author{
Michael Rand*
}

\begin{abstract}
The article offers an overview of the corpus of poetic disputes between the months composed in Aramaic, together with a critical edition of one such poem, איתחברו ירחי שתא by Sahlan ben Avraham (Fustat, 11 th century). The critical edition is accompanied by translations of the poem into Hebrew and English. Part of the text given in the critical edition is based on a copy found in a Genizah document copied in the 13th century by Yedutun Ha-Levi, now known as סדר פוסטאט. The history of publication of this document is reviewed, and a description of its remaining fragments (including a new fragment identified as part of the present edition) is given.
\end{abstract}

\section{INTRODUCTION: ARAMAIC DISPUTES BETWEEN THE MONTHS}

The corpus of Late Antique Jewish Palestinian Aramaic poetry ${ }^{1}$ may be conveniently divided into three categories on the basis of the Sitz im Leben of the poems: 1) poems that are connected in one way or another to the liturgical reading of the Aramaic Targum (i.e., socalled Targum poetry), 2) poems that are intended for para-liturgical occasions, in particular wedding poems and dirges, and 3) poems that are intended for incorporation into the liturgy proper. ${ }^{2}$ Cutting across this three-way distinction on the basis of locus (i.e., appearing in all three categories) is a literary type whose position within the corpus is quite prominent: the dialogue poem. In turn, a special sub-category of this type is the dispute poem. Dialogue poems in general and dispute poems in particular are of great interest to those who wish to trace the origins and development of Jewish Aramaic poetry on account of the fact that they are well attested in the roughly contemporaneous Christian Syriac poetic culture. Taken together with additional parallels between the two traditions, this shared feature points in the direction of the existence of a Late Antique Levantine aesthetic, which finds expression in

\footnotetext{
* Lecturer in Hebrew and Aramaic, University of Cambridge. Email: qalir@yahoo.com

${ }^{1}$ This corpus has been conveniently collected in M. Sokoloff and J. Yahalom, שירת בני מערבא (Jerusalem: The Israel Academy of Sciences and Humanities, 1999). Several of its aspects are the subject of an extensive and penetrating analysis by M. Kister, "שירת בני מערבא - היבטים בעולמה של שירה עלומה", Tarbiz76 (2006/07), 105-84.

${ }^{2}$ The first two categories reflect the status of Aramaic as the vernacular of Late Antique Palestine. Given the present state of our knowledge of the corpus, the third category is essentially restricted to qinot, i.e., poetic dirges composed for the liturgy of the Ninth of Av. For an analysis of this group of poems, see M. Rand, "Observations on the Relationship between JPA poetry and the Hebrew Piyyut Tradition - The Case of the Kinot," in Fewish and Christian Liturgy and Worship: New Insights into Its History and Interactions, eds. A. Gerhards and C. Leonhard (Leiden: Brill, 2007), 127-44. There is no reason to suppose that a relationship of dependence exists between the Aramaic and Hebrew qinot - i.e., that the former are somehow an imitation of the latter, or vice versa. It is quite likely that at some point in Late Antiquity, Aramaic and Hebrew qinot were simply composed alongside one another, with the Hebrew qinot eventually winning out by being incorporated permanently into the liturgy (with the result that the genre was cultivated and developed by successive generations of liturgical poets) while the Aramaic qinot were discarded, to be re-discovered among the literary remains preserved in the Cairo Genizah.
} 
the poetic corpora of the various relevant Aramaic literary cultures - Christian Syriac, Jewish Aramaic and Samaritan - and, by extension, in the traditions of Hebrew piyyut and Greek Church poetry, which are closely related to the Jewish and Christian corpora, respectively. ${ }^{3}$ In the case of dispute poems, moreover, the existence of the genre in both Jewish Palestinian Aramaic as well as Syriac is to be attributed to a common ancestry, since such poems are attested in the Mesopotamian, Sumero-Akkadian tradition, which constitutes a substratum of Aramaic literary culture. ${ }^{4}$

Among the dispute poems, a coherent group is constituted by those which describe a precedence dispute between the months of the year. One such poem is attested in Syriac, ${ }^{5}$ and the following examples are known in Jewish Aramaic: ${ }^{6}$

- איתחברו ירחי שתא ithabbaru yarhe shatta "The months of the year joined together": This is the only poem in the list by a known author: Sahlan ben Avraham. A discussion and critical edition are provided below.

- איתכנשו כל ירחיא itkannashu kol yarhayya "All the months gathered" (2): Published in M. Klein, Genizah Manuscripts of Palestinian Targum to the Pentateuch (Cincinnati: Hebrew Union College Press, 1986), 1.186-89. This poem is attested in ms. T-S NS 186.21, photographs of which are given in ibid., 2.163-64.

- ובי סלק משה and Yahalom, שירת בני מערבא, 238-39 and Klein, Genizah Manuscripts, 1.190-1. This poem is attested in ms. T-S H 10.78, photographs of which are given in ibid., 2.176.

- התכנשון כחדה כל ירחייה itkannashun ka-ḥada kolyarhayya "All the months gathered together" (7): Published in Sokoloff and Yahalom, שירת בני מערבא כ230-4 and Klein, Genizah Manuscripts, 1.201-5. This poem is attested in ms. T-S H 11.51, photographs of which are given in ibid., 2.165-171. Strictly speaking, it is not a dispute, as only Nisan speaks,

\footnotetext{
${ }^{3}$ See O. Münz-Manor, "Liturgical Poetry in the Late Antique Near East - A Comparative Approach," Fournal of Ancient fudaism 1 (2010), 336-61.

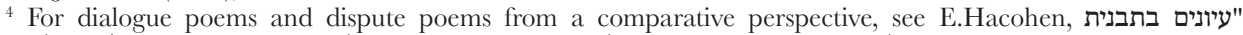
"הדיאלוגית בפייטנות הארץ ישראלית הקדומה ובמקורותיה לאור פיוטי הרחבה דיאלוגיים לפורים, Jerusalem Studies in Hebrere

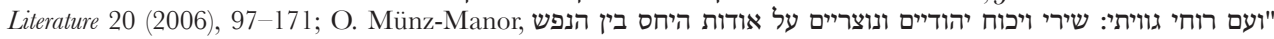
"והגוף, in Textures - Culture Literature Folklore for Galit Hasan-Rokem (Jerusalem: The Mandel Institute of Jewish Studies, Faculty of Humanities, Hebrew University of Jerusalem; 2013), 1.187-209; R. Murray, "Aramaic and Syriac Dispute-Poems and Their Connections," in Studia Aramaica: New Sources and New Approaches, eds. J. Greenfield, M. Geller, and M. Weitzman (Oxford: Oxford University Press, 1995), 157-87. For Syriac dispute poems, see S.P. Brock, "A Dispute of the Months and Some Related Syriac Texts," FSS 30 (1985), 181-211; idem, "Syriac Dispute Poems: The Various Types," in Dispute Poems and Dialogues in the Ancient and Mediaeval Near East, eds. H. Vanstiphout and G. Reinink (Louvain: Peeters, 1991), 109-19. For a discussion of the poetic debate in Hebrew

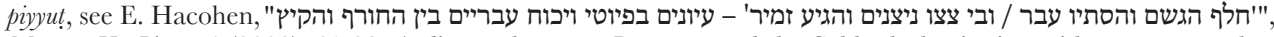

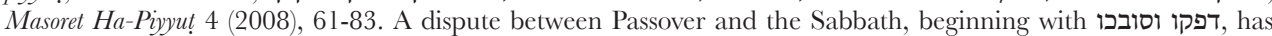
recently been added to the corpus of Hebrew dispute piyyuțim: see M. Rand, "Qillirian Compositions for Double Liturgical Occasions: Linguistic and Iconic Aspects (Including an Appendix with Editions of Two New Shivatot for Shabbat and Pesah)," in The Experience of Jewish Liturgy - Studies Dedicated to Menahem Schmelzer, ed. D.R. Blank (Leiden/Boston: Brill, 2011), 222-5.

5 This poem is published in Brock, "Dispute of the Months."

${ }^{6}$ A similar list is provided in Murray, "Aramaic and Syriac Dispute-Poems," 166-8. Murray did not have the advantage of being able to refer to Sokoloff and Yahalom, שירת בני מערבא (as he himself notes on p. 165, note 37). In any case, the list given here updates that of Murray. Where relevant, the number of the poem in Murray's list is indicated in parentheses immediately following the incipit in the list given above. Poem 6 on Murray's list is זהרה לקידוש ירחין itbeher zahra le-qiddush yarhin "The moon was chosen for the sanctification of the months" (Sokoloff

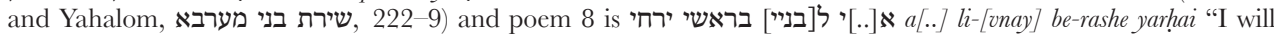
[...] my sons on my new moons" (ibid., 234-9). Neither poem is a dispute, as noted by Murray himself.
} 
addressing each of his opponents in turn and arguing for the inadmissibility of each to be the "Redeemer" month. The poem is therefore the exact opposite of a precedence debate, as each of the months (with the exception of Nisan) is (dis)qualified by reference to some negative feature. ${ }^{7}$ However, it shares enough features with the other items in this list to justify its inclusion (see below).

Where data are available, we see that the poetic disputes, which serve as targumic embellishments of החדש הזה לכם ראש חדשים ראשון הוא לכם לחדשי השנה (Exod. 12:2), are cast in the same basic mold. Each begins with an introduction, in which the gathering of the months is described. The theme of gathering is given expression in the opening lines of the poems, which are essentially stereotypical: איתחברו ירחי שתא, איתכנשו כל ירחיא אית each month in turn, beginning with Iyyar (i.e., the month immediately following Nisan). In the case of אתכנשון כחדה כל ירחייה, this feature is paralleled by the fact that Nisan begins his tirade against his opponents with Iyyar. There are several possibilities for the end of the debate. In איתחברו ירחי שתא the closing argument is given by Nisan, with the specification that his claim rests on the "authority of the Most High" (1. 60). The victory of Nisan is therefore implied rather than asserted explicitly. In איתכנשו כל ירחיא Nisan does not present arguments. Rather God, the presiding judge, rules in favor of Nisan immediately following Adar's arguments. In the case of אתכנשון כחדה כל ירחייה, after Nisan finishes his harangue with Adar, he pronounces himself the victor, again on God's authority: "The Mighty One made me a redeemer for his people" (1. 44; translation mine).

In addition to the poems listed above, the following two items should also be noted:

- והוה כיון דאיתגלי "va-hava kevan de-itgele YY "And when the Lord was revealed" (1, 5): This dispute between the months is not cast in a poetic form, but rather in that of a prose targum expansion (tosefta) to Exod. 12:2. The literary structure of this expansion, however, entirely corresponds to that of the poetic disputes. It is attested in two versions, which are recensions of the same basic text. The first recension is published in M. Klein, The FragmentTargums of the Pentateuch (Rome: Biblical Institute Press, 1980), 1.72-3. A translation is given in ibid., 2.37-39. An alternative translation, including suggested emendations to the Aramaic text, is provided by Brock, "Dispute of the Months," 209-211. The second recension, beginning with va-hava kad itgele qiris "And when the Lord was revealed", is published in Klein, Genizah Manuscripts, 1.194-5. It is attested in ms. Ox. Heb. e.73, photographs of which are given in ibid., 2.173-74.

- אתרמי פולומוס itreme polemos [transcription following the vocalization in the manuscript] "A dispute arose" (4): This short targumic poem to Exod. 12:2, which at present consists of four stanzas, has been published on several occasions, the two latest being: Kister, "השיבוּרטים", 115 A. Berberian, "תששבחות/תוּשבחות: עדויות חדשות ופשרן", Leshonenu 75 (2012), 112. It is attested in ms. Ox. Heb. e.73 (see previous item). In its present form, it appears foreshortened, with the first two stanzas describing the gathering of the months and their resolve to cast lots so as to determine which of them will be the month of

\footnotetext{
7 This poem is further distinguished from the other debate poems by the fact that in it the months are identified with their respective zodiac signs.

${ }^{8}$ The latter two incipits are simply textual variants. In the case of the third incipit the word כחדה is crossed out in the manuscript.
} 
Israel's redemption, while in the third and fourth stanzas Nisan summarily dismisses his opponents, claiming the prize for himself.

\section{SAHLAN'S POEM}

The poem איתחברו ירחי שתא ithabbaru yarhe shatta "The months of the year joined together" was composed by Sahlan ben Avraham, whose acrostic signature appears in the last stanza: סהלאן. Sahlan was a prominent member of the Babylonian community in Fustat, and was active in the beginning of the 11 th century. ${ }^{10}$ His poem therefore postdates the other, Late Antique, poetic disputes listed above by some 500 years. However, its inclusion within the present corpus is amply justified on the grounds of its structural similarity to the Late Antique poems. In terms of overall structure, we have already seen that all of the poems begin with Iyyar and end with the victorious Nisan. More specifically, Sahlan's poem contains a number of verbal parallels to the poems איתכנשו כל ירחיא itkannashu kol yarhayya "All the months

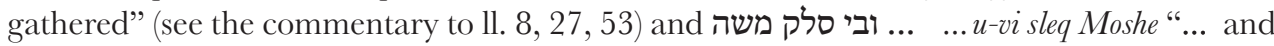
in me Moses went up" (see the commentary to ll. 13-14, 19, 28, 29, 32, 35, 38, 48). In fact, Fleischer, who first published Sahlan's poem (see below), noted the parallels between it and and correctly judged the latter to have served as a model for the former. ${ }^{11}$ Finally, as with the Late Antique poems, Sahlan's poem also seems to have been originally intended as a targumic embellishment of Ex. 12:2, as indicated by the fact that the targum to this verse is referred to in its last line (see the commentary, ad loc.). As a faithful imitation, therefore, Sahlan's poem may be considered an additional witness to the essentially Late Antique genre under discussion here. ${ }^{12}$

Sahlan's poem is distinct from the Late Antique debate poems in the matter of dialect. Whereas the latter were intended for use with the Palestinian Targum and (for the most part) reflect the Jewish Palestinian Aramaic idiom in which it was composed, the former was to be employed with Targum Onqelos (see note 14), and is composed in an Aramaic that imitates that of this Targum, with occasional slips into Babylonian Aramaic: קמר "before" (1. 12), "the Lord" (1. 37), הרמון "He taught" (1. 41), authority, permission" (1. 60; see the commentary, ad loc.). ${ }^{13}$

\footnotetext{
${ }_{9}$ The poet appears to have signed his name twice. In the first case, $\delta$ is found in the partially preserved word

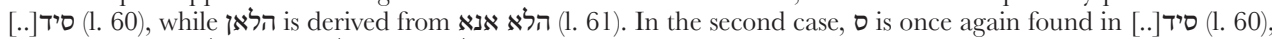

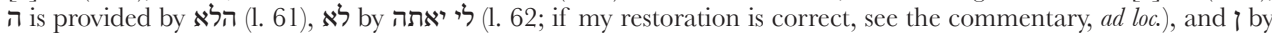
נהוריה (1. 63).

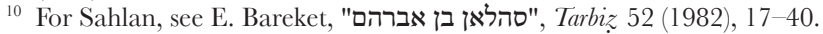

11 See E. Fleischer, "עוד לעניין 'ראש ראשי חברשם", Sidra 7 (1991), 56-57, note 18.

12 Sahlan composed a second Aramaic poem in honor of Nisan: elaha addira shemeh "His name is Mighty God" - published in E. Fleischer, "ראש ראשי חדשים", Tarbiz 37 (1968), 269-70. This poem, however, does not belong to the dispute genre.

13 The poem also contains two morphological Hebraisms: כולן "all of them" (1. 51), פירש "He expounded" (1.53) together with two apparent lexical Hebraisms: עדי "wearing" (1. 27), דבר "He spoke" (1. 58). Incidentally, the latter usage seems to also be attested in סגין דבר ירחא מרחשון :... ובי סלק :1. 21). In their commentary, the editors opine that the meaning of דבר is unclear in the present context. It seems likely, however, that the correct translation is "Marheshvan spoke great things (or: spoke at length)." This interpretation is reinforced by the fact that the first line of every strophe of this poem contains some verb of speech, and line 21 is the opening line of the strophe dedicated to Heshvan.
} 


\section{THE FIRST ORDER OF FUSTAT}

At present, Sahlan's poem is attested within the context of a qiddush ceremony in honor of the New Moon of Nisan that was celebrated on the eve of the New Moon in the "Palestinian" synagogue of Fustat in the beginning of the 13th century. ${ }^{14}$ This ceremony is primarily attested in a document of central importance for the study of (the last phase of) the Palestinian liturgical ritual, the bulk of which is preserved in ms. T-S H $12.11 .^{15}$ The document is currently known as סדר פוסטאט א, "The First Order of Fustat." In the course of preparing an edition of Sahlan's poem, it became evident that more fragments of this document have been preserved than has hitherto been recognized. In order to underscore this point, it is necessary to briefly review the history of its publication.

In an article entitled "ראש ראשי חדשים" (1968), Fleischer called attention to ms. T-S H 12.11, a liturgical document consisting of three bi-folia, which he divided into two groups of three folia each (i.e., the three bi-folia belong to the same quire, with a gap between the first three and the last three folia): 1) Purim, Parshat Parah, Parshat Ha-Hodesh, Rosh Hodesh Nisan; 2) Simhat Torah, Shabbat Ve-Zot ha-Berakha, Shabbat and Rosh Hodesh, Shabbat Parshat Yitro, Hanukkah. ${ }^{16}$ Fleischer later published a facsimile of this manuscript, in which the order of the two groups is reversed, so that the material for Rosh Hodesh Nisan now appears at the end of the preserved quire (rather than in the middle, at the end of the first three folia).$^{17}$ As we will see presently, the latter is the correct order. In the same article, Fleischer announced the discovery of an additional bi-folium belonging to the same document, only the bottom halves of whose leaves are preserved: T-S $13 \mathrm{H} 3.11$. One leaf of this bi-folium contains material for Rosh Hodesh Nisan, while the other leaf contains the remains of text in the upper portion of the recto, the rest of the recto and the verso being left empty. The material for Rosh Hodesh Nisan follows the material for the same occasion contained in T-S H 12.11.

In his publication, Fleischer ignored the fact that T-S $13 \mathrm{H} 3.11$ is a bi-folium (here and in subsequent publications, he consistently refers to the manuscript as a דף, "folio"), whereas

\footnotetext{
14 Though the present context of the poem is liturgical, we must distinguish between the core, statutory liturgy and various liturgical occasions bearing a semi-popular character, of which the present case is one. A similar view is taken by Fleischer, "עוד לעניין", 63, who refers to "the explicitly popular character" of the qiddush ceremony, calling it "a sort of spring festival" (transl. mine). The poem's basic function as a targumic embellishment is clearly indicated by its referring to the targum in its last line (see above), together with the fact that in the manuscript (T-S $13 \mathrm{H} \mathrm{3.11)}$ it is immediately followed by material from Targum Onqelos: Ex. 12:3 (followed by a short Aramaic litany), Ex. 12:1-3 (for the text, see Fleischer, "ראש ראשי חדשים", 272-3). The view expressed here is pace Fleischer, "עוד לעניין", 63, note 35, who argues that the poem, together with its predecessors, was composed specifically for the festive qiddush ceremony. Firstly, Fleischer admits a logical inconsistency in referring to this ceremony as being both "popular" (see above) and "official" (thus in note 35). Furthermore, it is clear that the collection of poems employed in this ceremony is highly eclectic, as noted already in ibid., 57 . Sahlan's targumic embellishment is therefore simply just another genre thrown into this eclectic mixture, and there is no particular reason to believe that it was written ab initio for the occasion. The fact that it is composed in Aramaic in no way singles it out, as other Aramaic elements not belonging to the dispute genre are also employed in the same ceremony (see for instance note 12).

${ }_{15}$ This is the shelf-mark as it appears on the casing of the manuscript. In the publications that will be reviewed below, Fleischer refers to it mostly as T-S H 12.11a.

${ }_{16}$ Fleischer,"ראש ראשי חדשים", 266-7.

17 The facsimile appears at the end of E. Fleisher, תפילה ומנהגי תפילה ארץ-ישראליים בתקופת הנניזה (Jerusalem: Magnes, 1988). A facsimile of the verso of the leaf containing the material for Rosh Hodesh Nisan is also given in Klein, Genizah Manuscripts, 2.172. The image is labeled "folio 6v," indicating that Klein also positions the leaf last in the preserved quire.
} 
this fact actually solves the problem of the order of the two groups in the three bi-folia of T-S H 12.11. As noted above, the second leaf of T-S $13 \mathrm{H} 3.11$ is blank in the bottom of the recto and in the entire verso. The most likely assumption, therefore, is that this leaf constitutes the end of the original codex. This being the case, the only possible juxtaposition between the two manuscripts is one in which the material for Rosh Hodesh Nisan contained in T-S $13 \mathrm{H} 3.11$ follows the material for the same occasion contained in T-S H 12.11, while at the same time the second, partially blank, leaf of T-S $13 \mathrm{H} 3.11$ is positioned last among the leaves of the two manuscripts. These two criteria can only be satisfied if the three bi-folia of T-S H 12.11 are grouped together in one quire with the material for Rosh Hodesh Nisan last, while the bi-folium T-S $13 \mathrm{H} 3.11$ is positioned as the outer bi-folium of the following quire, with the leaf containing material for Rosh Hodesh Nisan coming first.

In his article, Fleischer published the material for Rosh Hodesh Nisan contained in the first leaf of T-S $13 \mathrm{H} \mathrm{3.11.} \mathrm{At} \mathrm{the} \mathrm{preserved} \mathrm{top} \mathrm{of} \mathrm{the} \mathrm{recto} \mathrm{he} \mathrm{recognized} \mathrm{the} \mathrm{damaged}$ remains of the tail end of a poem containing a dispute between the months, surmising that it might belong to the poem אתרמי פולומוס. ${ }^{18}$ At the beginning of the corresponding verso, he identified the damaged text of the qiddush itself. ${ }^{19}$ As we will see presently, the end of the

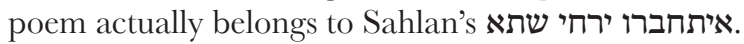

In a follow-up article, "חדשות לעניין 'ראש ראשי חדשים" (1981), Fleischer published ms.

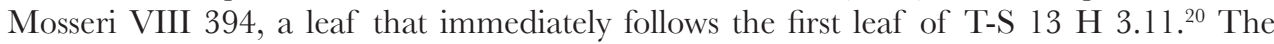
number of known manuscripts belonging to the First Order of Fustat thus rose to three.

In a third article on the subject, "עוד לעניין 'ראש ראשי חודשים" (1991), Fleischer identified ms. T-S NS 236.5, which does not belong to The First Order of Fustat, but also contains (poetic) material pertaining to Rosh Hodesh Nisan. ${ }^{21}$ The parallel to the First Order of Fustat was established on the basis of a poem appearing in both documents: אלהא אדירא שמיה elaha addira shemeh "His name is Mighty God" (see note 12). After this poem, T-S NS 236.5 contains the beginning of איתחברו ירחי שתא, which Fleischer published.22 He then published the continuation of איתחברו ירחי שתא on the basis of ms. T-S NS 125.96, and its direct continuation, ms. T-S NS 325.69. ${ }^{23}$ However, it escaped Fleischer's notice that T-S NS

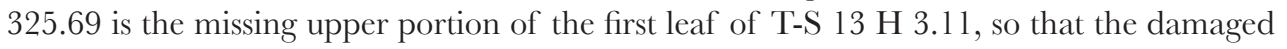
tail end of the dispute poem appearing at the top of the recto of T-S $13 \mathrm{H} 3.11$ belongs to this copy of איתחברו ירחי שתא. ${ }^{24}$

Accordingly, the number of known manuscripts containing fragments of the First Order of Fustat is five. These constitute the remains of two adjacent quires, the latter presumably

\footnotetext{
${ }_{18}$ Fleischer, "ראש ראשי חודשים", 272, 277.

19 Fleischer, "ראש ראשי חודשים", 274, 277.

20 E. Fleischer, "חדשות לעניין 'ראש ראשי חדשים", in Studies in Aggadah, Targum and Fewish Liturgy in Memory of Foseph Heinemann, eds. J.J. Petuchowski and E. Fleischer (Jerusalem: Magnes, 1981), 111-32 [Hebrew section].

21 Fleischer, "עוד לעניין", 49-65.

22 Fleischer, "עוד לעניין", 52.

23 Fleischer, "עוד לעניין", 53-5.

${ }^{24}$ Fleischer came tantalizingly close to recognizing that the two manuscripts represent the same source. In his discussion of איתחברו ירחי שתא he cites as a typological parallel the tail end of the dispute poem in T-S 13 H 3.11, again opining (this time without any hesitation) that it belongs to אתרמי פולומוס - see Fleischer, "עוד לעניין", 56, note 17. Furthermore, he recognized that the actual qiddush ceremony described on the verso of T-S NS 325.69 is

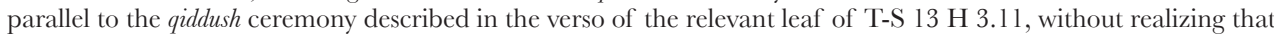
these are two halves of one and the same text - see ibid., 56 (in the notes to the transcription).
} 
being the last of the original codex. The first quire is constituted by the three consecutive bi-folia making up T-S H 12.11, with the material for Rosh Hodesh Nisan coming last. The last folio of this quire is represented by the leaf preserved as T-S NS 125.96. The first folio of this quire, i.e., first leaf of the original bi-folium whose second leaf is T-S NS 125.96, is missing. (If, therefore, we assume a quire consisting of five bi-folia, it necessarily follows that a single, inner bi-folium is missing from this reconstructed quire.) The second quire, which

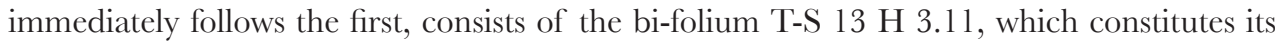
outer bi-folium. The upper portion of the first leaf of T-S 13 H 3.11 is T-S NS 325.69. This first leaf is followed by another: Mosseri VIII 394.

In a final article treating of the document under discussion here, Fleischer summarized his findings and named it סדר פוסטאט א..25 In an important discovery, he also identified the compiler/copyist of this document: Yedutun Ha-Levi. Yedutun was the hazzan of the Palestinian synagogue in Fustat in the first quarter of the 13th century, a poet in his own right, whose career is chiefly identified with his unflagging and ultimately unsuccessful efforts to save the remaining vestiges of the Palestinian liturgical rite from being abrogated in favor of the triumphant Babylonian rite. ${ }^{26}$ The First Order of Fustat was drawn up by Yedutun as part of his campaign.

\section{CRITICAL EDITION}

Below I provide a critical edition of Sahlan's dispute poem, on the basis of:

- T-S NS 236.5 (1l. 1-15)

- T-S NS 125.96, T-S NS 325.69/T-S 13 H 3.11 (1l. 19-63)

A composite image of T-S NS 325.69/T-S 13 H 3.11 may be viewed on the website of the Taylor-Schechter Genizah Research Unit. ${ }^{27}$ As the two manuscript witnesses do not overlap, restorations in square brackets are always conjectural. A Hebrew translation is provided alongside the Aramaic text. An English translation is provided in the following section.

Editorial Sigla:

- $[.$.$] = less than one word missing$

- $[\ldots]=$ one word or more missing (may be repeated in order to fill out a line)

- $<>=$ restoration of a scribal abbreviation

- $\dot{\boldsymbol{\kappa}}=$ doubtful reading

\footnotetext{
${ }^{25}$ E. Fleischer, "לסדרי התפילה בבית הכנסת של בני ארץ-ישראל בפוסטאט בראשית המאה השלוש עשרה", Asufot 7 (1993) 217-60.

${ }^{26}$ For Yedutun and his career, see Sh. Elizur, "שירי ר' ידותון הלוי החבר in Diné Israel - Studies in Halakhah and Fewish Law 26-27 (2009/2010) 301-8 [Hebrew section].

${ }^{27}$ Website: http://www.lib.cam.ac.uk/Taylor-Schechter/fotm/november-2011/index.html (Fragment of the Month, November 2011).
} 
אחר

התחברו ירחי השנה

באורך הזמן כאשר היתה העת

בהשיבם מלה מלה

כל אחד אמר לי יאָה גדולה מלה מלה

גילה אייר טעם מילולו

וענה וחבריו למולו

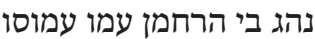

והוריד לו המן ואוכלו עמו עמוס

הלא סיון להם ענה

כראוי מעשה היאֶה הוא נחשֶב לפיון לפני הרם

ובי עלה משה למרום

והוריד שני לוחות הברית משר למרום

אשרַי אמר אב מכל ירח והתנשא עליהם להשתבח

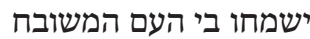
שבי יתנחמו אבלים ובי יוולד המשיח

כאשר שמע אלול זאת מילה

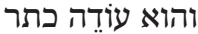

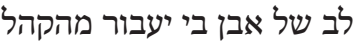
ותיבנה הקריה היקרה להשתכל אבל יעבור מהקל

מי כמוני בכלכם אמר תשרי שבי רוצה רבוני ומרי כמוני בכיכם

מזהירים בי עמו בצאת [...] וירבו בי חג ויתוסף שפרי בי עמו בצתי

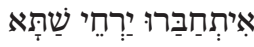

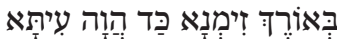

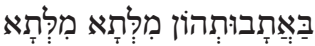

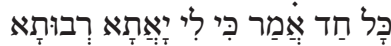

$$
5
$$

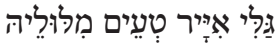

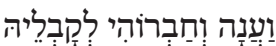

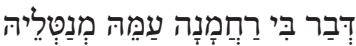

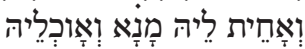

10

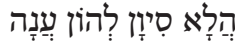

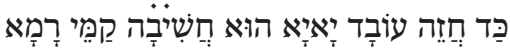

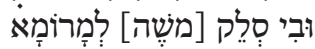

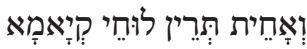

15

$[\ldots \ldots \ldots$

$[\ldots \ldots \ldots \ldots \ldots \ldots]$

$[\ldots \ldots \ldots$

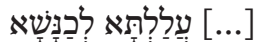

20

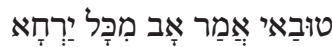

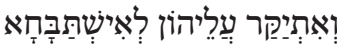

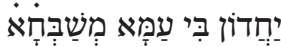

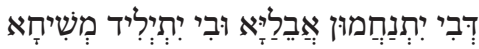
25

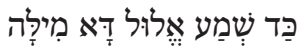

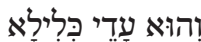

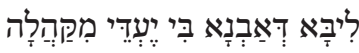

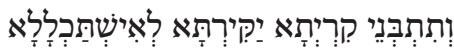
30

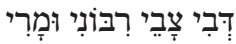

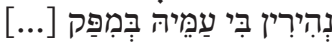

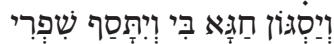


פז>>מון>

רוב מילים הרבה מרחשון אמר להם אני זה שעשיתי לבוש משון לבושים עשה האדון בי ניסים וניצחו בני חשמוני על מלכי הים יון

פיו פתח כסליו ואמר ולחבריו דיבורו לימד פסייו ואמר תפילותם של העם [-...] ומציקם נשבר ונעלם העם

קם טבת [...] ואני בי הציל הרחמן האומה גדלה בי [...] וביטלתי גזרה של המן בן המדתא שבט [...] ובדה ועל כולן התנשא [...] ובדרי השבח [...] שבי ביאר משה לימוד התורה הזאת וענה וחבריו לפניו עטרה לי היא [...] שבי נולד ענו שדיבר עמו

[...] של ניסן [...] ברשות עליון הלא אני ראש וכל ירח אחרון

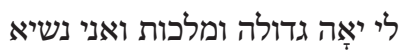
אורי אור גדול ואני הירח הראשות ואניאון
35

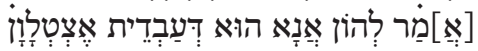

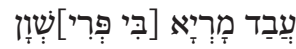

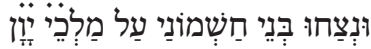

פזו>מון

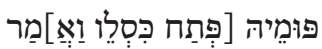
40

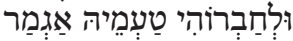

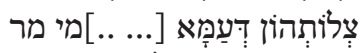

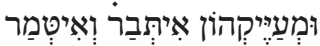

פז>מון>

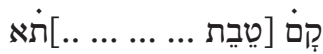

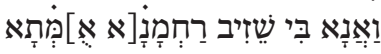
רְבָת בִּי [................

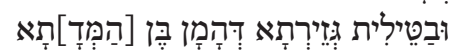

פז>מון> 50

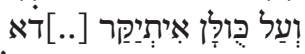

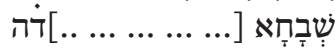

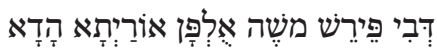
פז>מון> ה] 55

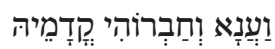

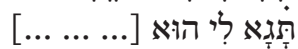

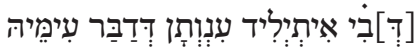

פז>מון>

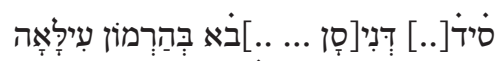
60

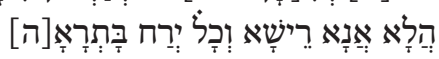

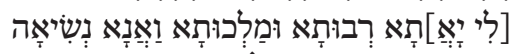

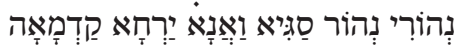

שלם קיצא דבני יתיב חברון / על יד משה ואהר[ו] 


\begin{abstract}
קיצורים
נעם = ו' נעם, מגילת תענית, ירושלים תשס"ד (2003)

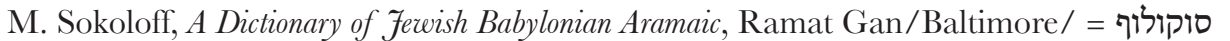

London 2002

• "איתכנשו כל ירחיא" = מהד' קליין (ראה ברשימת הפיוטים בגוף המאמר) (ראירוף

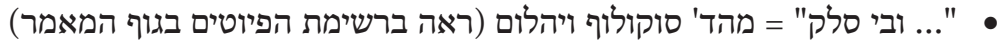

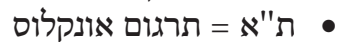

פירוש הפיוט

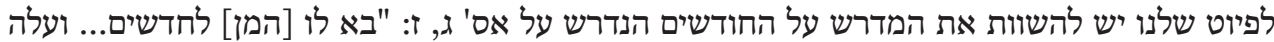

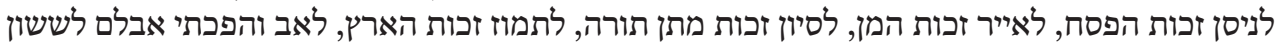

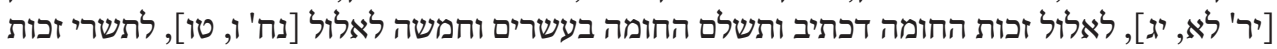

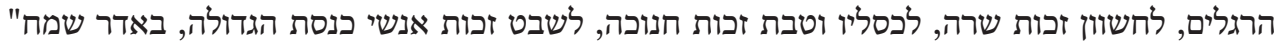

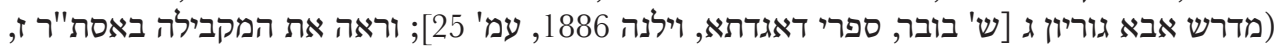

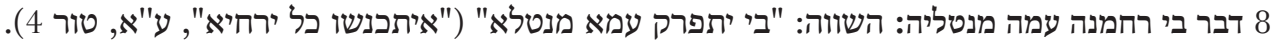

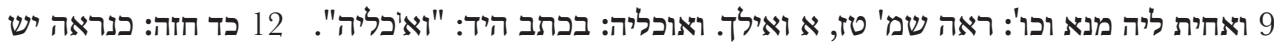

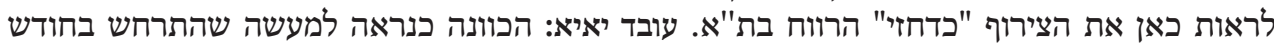

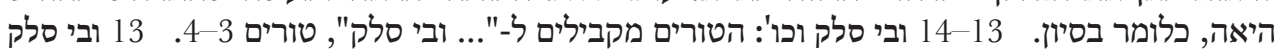

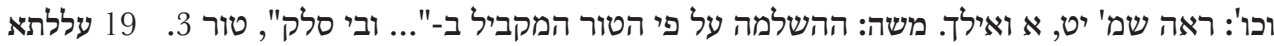

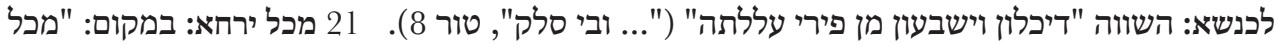

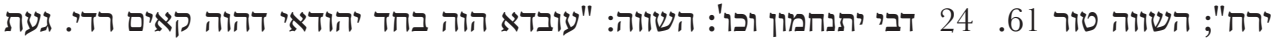

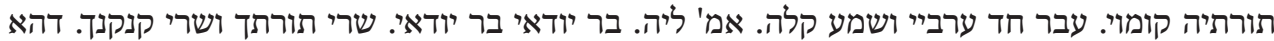

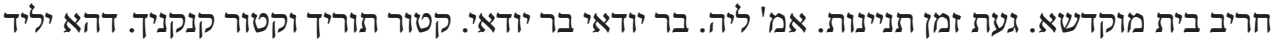
מלכא משיחא" וגו' (ירושלמי ברכות ב, ג' [ה ע" ע"א]

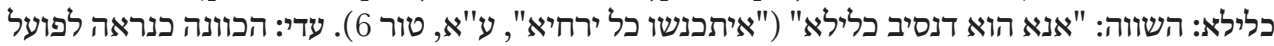

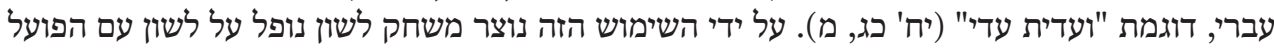

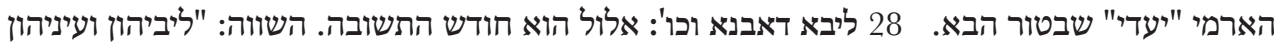

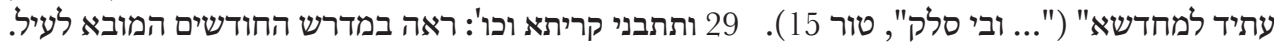

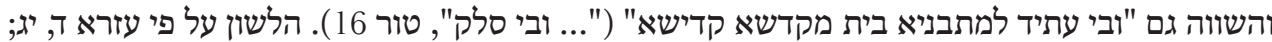

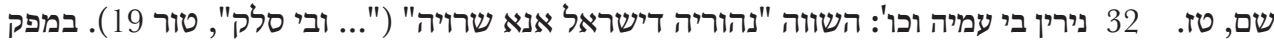

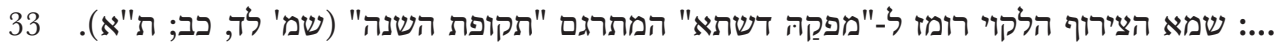

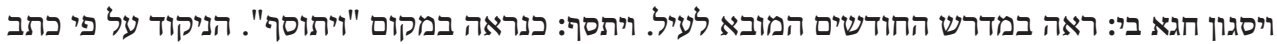

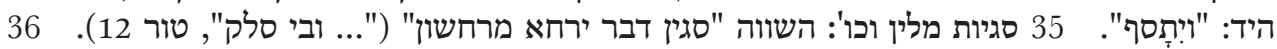

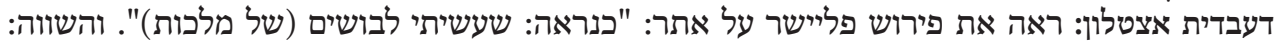

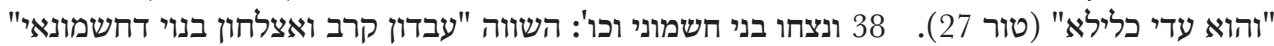

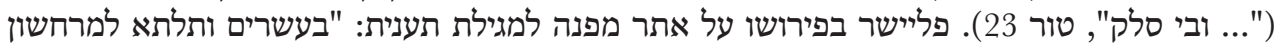

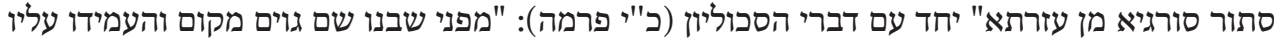

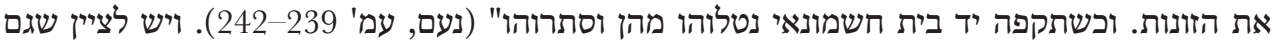

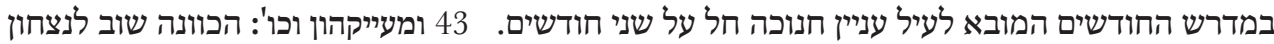

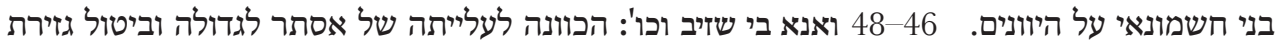

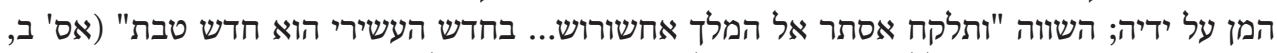
טז). 48 ובטילית גזירתא: ללשון השווה "ובטלת גזירה" ("... ובי סלק", טור 11). 53 (1) דבי פירש וכו': 


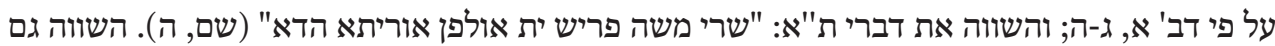

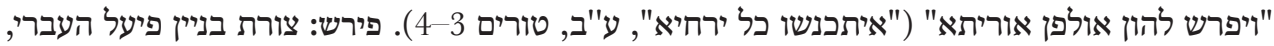

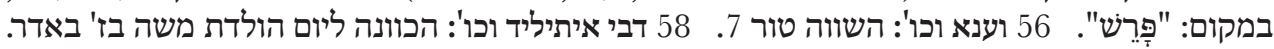

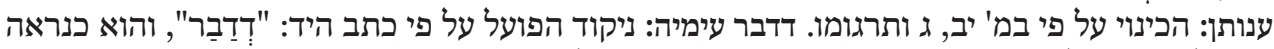

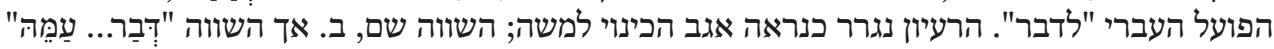

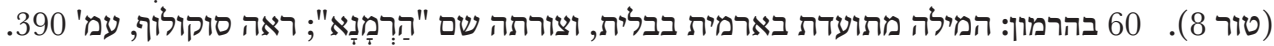

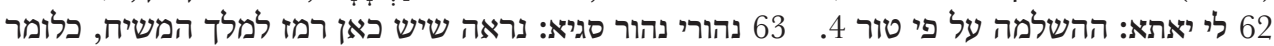

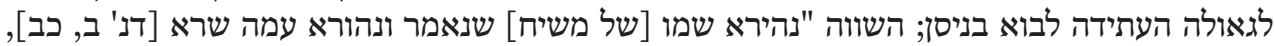

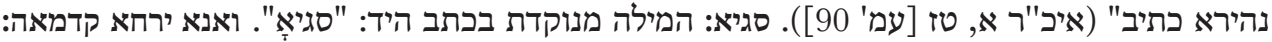

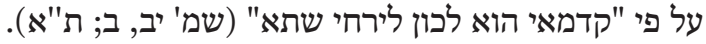

\section{TRANSLATION}

The months of the year joined together

In the length of time, when the moment arrived.

In bandying about words

Each one said, "Preeminence is my due."

$5 \quad$ Refrain

Iyyar lay bare the meaning of his talk

And spoke, his fellows before him.

"In me the Merciful One led out the people borne by Him,

And brought down for them manna and food."

10 Refrain

Indeed Sivan answered them,

"As is fitting, the deed of one worthy is reckoned before the High One.

And in me Moses ascended on high

And brought down the two Tablets of the Covenant."

$15 \quad$ [Refrain $]$

$[\ldots]$

$[\ldots]$

$[\ldots]$

[...] to gather the harvest.

20 Refrain: In bandying about

"Blessed am I," said Av, "among all the months."

And he esteemed himself above them, giving himself praise.

"In me the praised nation will rejoice

For in me mourners will be consoled and in me the Messiah will be born."

25 Refrain

When Elul heard these words,

He wearing the crown, 
[He said,] "In me the heart of stone will pass from the congregation And the precious city will be rebuilt to perfection."

30 "Who is like unto me amongst you all," said Tishrei,

For it is in me that my Lord and Master takes pleasure.

His people are radiant in me, at the going out of [...]

And they multiply feasts in me, and my splendor waxes."

Refrain

35 Marheshvan multiplied a plethora of words.

He said to them, "I am he who made garments.

The Lord performed miracles in me

And the sons of Hashmonay were victorious over the kings of Greece."

\section{Refrain}

$40 \quad$ Kislev opened his mouth and said,

Instructing his fellows in his meaning.

"The people's prayer $[\ldots]$

And their oppressor was smashed and disappeared."

\section{Refrain}

$45 \quad$ [Ṭevet $]$ arose $[\ldots]$

"And as for me, in me the Merciful One saved the nation.

In me $[\ldots]$ became great,

And I abrogated the decree of Haman the son of Hamdata."

\section{Refrain}

50 Shevat $[\ldots]$ and invented $[\ldots]$

And he esteemed himself above them all $[\ldots]$.

"Praise $[\ldots]$

For in me Moses expounded the teaching of this Torah."

\section{Refrain}

And spoke, his fellows before him.

"The crown is mine $[\ldots]$

For in me the humble one was born, with whom [God] spoke."

\section{Refrain}

$60[\ldots]$ of Nisan [...] by authority of the Most High.

"Am I not the head and every [other] month last?

Preeminence and kingship are my due, and I am the prince.

My light is a great light, and I am the first month." 


\section{BIBLIOGRAPHY}

Bareket, E., "סהלאן בן אברהם", Tarbiz 52 (1982), 17-40.

Berberian, A., "תשבחות/תוּשבחות: עדויות חדשות ופשרן", Leshonenu 75 (2012), 101-21

Brock, S.P., "Syriac Dispute Poems: The Various Types," in Dispute Poems and Dialogues in the Ancient and Mediaeval Near East, edited by H. Vanstiphout and G. Reinink (Louvain: Peeters, 1991), 109-19.

Brock, S.P., "A Dispute of the Months and Some Related Syriac Texts," FSS 30 (1985), 181-211

Elizur, S., "שירי ר' ידותון הלוי החבר", Diné Israel - Studies in Halakhah and Fewish Law 26-27 (2009/2010), 301-8 [Hebrew section].

Fleischer, E., "לסדרי התפילה בבית הכנסת של בני ארץ-ישראל בפוסטאט בראשית המאה השלוש עשרה", Asufot 7 (1993), 217-60.

Fleischer, E., "'עוד לעניין 'ראש ראשי חודשים", Sidra 7 (1991), 49-65.

Fleischer, E., תפילה ומנהגי תפילה ארץ-ישראליים בתקופת הגניזיז 'רשים (Jerusalem: Magnes, 1988).

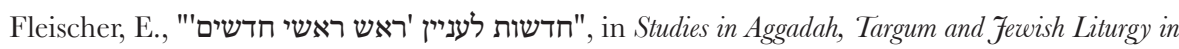
Memory of Foseph Heinemann, edited by J.J. Petuchowski and E. Fleischer (Jerusalem: Magnes, 1981), 111-32 [Hebrew section].

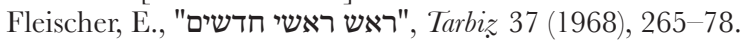

"'"חלף הגשם והסתיו עבר / ובי צצו ניצנים והגיע זמיר' - עיונים בפיוטי ויכוח עבריים בין החורף,"אשים", Hacohen, E "והקיץ, Masoret Ha-Piyyut 4 (2008), 61-83.

Hacohen, E. עיונים בתבנית הדיאלוגית בפייטנות הארץ ישראלית הקדומה ובמקורותיה לאור פיוטי הרחבה" "דיאלוגיים לפורים, Ferusalem Studies in Hebrew Literature 20 (2006), 97-171.

Kister, M., "שירת בני מערבא - היבטים בעולמה של שירה עלומה", Tarbiz 76 (2006/07), 105-84.

Klein, M.L., Genizah Manuscripts of Palestinian Targum to the Pentateuch (Cincinnati: Hebrew Union College Press, 1986).

Klein, M.L., The Fragment-Targums of the Pentateuch (Rome: Biblical Institute Press, 1980).

Münz-Manor, O., "Liturgical Poetry in the Late Antique Near East - A Comparative Approach," Fournal of Ancient fudaism 1 (2010), 336-61.

Münz-Manor, O., "ועם רוחי גוויתי: שירי ויכוח יהודיים ונוצריים על אודות היחס בין הנפש והגוף", in Textures - Culture Literature Folklore for Galit Hasan-Rokem (Jerusalem: The Mandel Institute of Jewish Studies, Faculty of Humanities, Hebrew University of Jerusalem; 2013), 1.187-209.

Murray, R., "Aramaic and Syriac Dispute-Poems and Their Connections," in Studia Aramaica: New Sources and New Approaches, edited by J. Greenfield, M. Geller, and M. Weitzman (Oxford: Oxford University Press, 1995), 157-87.

Rand, M., "Qillirian Compositions for Double Liturgical Occasions: Linguistic and Iconic Aspects (Including an Appendix with Editions of Two New Shivatot for Shabbat and Pesah)," in The Experience of Jewish Liturgy - Studies Dedicated to Menahem Schmelzer, edited by D.R. Blank (Leiden/Boston: Brill, 2011), 222-5.

Rand, M., "Observations on the Relationship between JPA Poetry and the Hebrew Piyyut Tradition The Case of the Kinot," in Fewish and Christian Liturgy and Worship: New Insights into Its History and Interactions, edited by A. Gerhards and C. Leonhard (Leiden: Brill, 2007), 127-44.

Sokoloff, M. and J. Yahalom, שירת בני מערבא (Jerusalem: The Israel Academy of Sciences and Humanities, 1999). 
